\title{
Maternal perceptions on Well Child Care ${ }^{1}$
}

\author{
Yolanda Flores-Peña ${ }^{2}$ \\ Rosario Edith Ortiz-Félix ${ }^{3}$ \\ Velia Margarita Cárdenas-Villarreal²
}

The aim was to analyze well child nursing care (WCC) and to distinguish if the care is procedure or user centered. The concepts of the nursing work process and the micro-politics of health work supported this qualitative study. Systematic direct observation of 87 WCC consultations was accomplished at one Family Medicine Unit and semistructured interviews were held with 25 mothers who attended WCC consultations with their child. Data saturation and understanding of the meaning were the criteria used to determine the number of observations and interviews. Thematic analysis was applied. The activity was focused on procedures, which cannot be considered WHCC. The mothers value comprehensive care and request information on the growth and development of their children. Educative topic should be addressed and trust relations should be established with a view to user-centered care delivery.

Descriptors: Child Care; Nursing Care; Child Health Services; Nursing Services; Maternal Child Nursing.

\footnotetext{
${ }_{1}^{1}$ Paper extracted from Doctoral Dissertation "O processo de trabalho da enfermeira no cuidado à criança sadia em uma Instituição da Seguridade Social do México" presented to Escola de Enfermagem de Ribeirão Preto, Universidade de São Paulo, WHO Collaborating Centre for Nursing Research Development, Brazil.

${ }^{2}$ PhD, Full Professor, Facultad de Enfermería, Universidad Autónoma de Nuevo León, Mexico.

${ }^{3}$ Master's Student, Facultad de Enfermería, Universidad Autónoma de Nuevo León, Mexico. Scholarship holder from Conacyt, process \# 334339.
}

Corresponding Author:

Yolanda Flores-Peña

Av. Gonzalitos, 1500 Norte

Col. Mitras Centro

C.P. 64460 , Monterrey, NL, México

E-mail: yolaflo@hotmail.com 


\section{Percepções maternas do Cuidado à Criança Sadia}

O objetivo do estudo foi analisar o Cuidado à Criança Sadia (CCS) e distinguir se é cuidado baseado nos procedimentos ou cuidado baseado no usuário. Os conceitos do processo de trabalho de enfermagem e micropolítica do trabalho em saúde fundamentaram o presente estudo qualitativo. Realizou-se observação sistemática direta de 87 atenções de CCS em uma Unidade de Medicina Familiar e entrevista semiestruturada a 25 mães que compareceram, junto a seu filho, à atenção de CCS. A saturação dos dados e a compreensão do significado foram os critérios para o número de observações e entrevistas. Aplicou-se a análise temática. Encontrou-se que a atividade está baseada nos procedimentos, o que não pode se considerar CCS. As mães valorizam a atenção integral e solicitam informação relacionada ao crescimento e desenvolvimento de seu filho. Recomenda-se abordar tópicos educativos e estabelecer relação de confiança que permita fornecer cuidado baseado no usuário.

Descritores: Cuidado da Criança; Cuidados de Enfermagem; Serviços de Saúde da Criança; Serviços de Enfermagem; Enfermagem Materno-Infantil.

\section{Percepciones maternas del Cuidado del Niño Sano}

El objetivo del estudio fue analizar el cuidado de enfermería del niño sano (CNS) y distinguir si se trata de cuidado centrado en procedimientos o centrado en el usuario. Los conceptos del proceso de trabajo de enfermería y micro política del trabajo en salud fundamentaron el presente estudio cualitativo. Se realizó observación sistemática directa a 87 consultas de CNS en una Unidad de Medicina Familiar y entrevista semi-estructurada a 25 madres que acudieron con su hijo a la consulta de CNS. La saturación de datos y comprensión del significado fueron los criterios para el número de observaciones y entrevistas. Se aplicó análisis temático. Se encontró que la actividad se centra en procedimientos, lo que no puede ser considerado CNS. Las madres valoran la atención integral y solicitan información del crecimiento y desarrollo de su hijo. Se recomienda abordar tópicos educativos y establecer relación de confianza que permita brindar cuidado centrado en el usuario.

Descriptores: Cuidado del Niño; Atención de Enfermería; Servicios de Salud del Niño; Servicios de Enfermería; Enfermería Materno-Infantil.

\section{Introduction}

Well child care (WCC) includes care delivery in acute and chronic episodes, as well as the coordination and monitoring of child development problems. Its components are: health supervision, growth and development assessment, psychosocial assessment of the child and family and immunizations ${ }^{(1)}$.

In Mexico, preventive pediatric care actions are addressed in the Official Mexican Standard for Child
Health Care, which appoints that integrated care delivery to children under five years of age at the health unit should consider the following aspects: vaccination surveillance, attention to the reason for the consultation, diet surveillance and education for the mother(2).

In the Social Security system, these aspects are part of the Diet, Growth and Development Program for children under five years of age (VNCD), a strategy 
for comprehensive medical care delivery with a view to enhancing the health level of this population group and bringing down malnutrition and morbidity-mortality rates for children under five years of age (3).

Social Security is the key component of the Mexican Health System, attends to almost $50 \%$ of the population and offers VNCD care at Family Medicine Units (FMU), which are the entry door to the health system, through a team that comprises a family doctor, social worker, psychologist, dentist, nutritionist, medical assistant to the maternal-infant nurse (AMIN) and the maternalinfant nurse (MIN). Family doctor follow the infant during the first three months of life, and then forward them to the MIN to continue VNCD up to the age of five years(3).

Specialized literature on the theme signals that the nursing consultation is a form of systemized and distinguished care delivery to the population. Likewise, the authors advert about the possibility of confounding the nursing consultation with procedures like anthropometric measures and the evaluation of vital signs, among others ${ }^{(4)}$.

For this study, nursing was considered an activity accomplished by people who use knowledge from other sciences and knowledge it has produced itself to apprehend the object of health in its specific field (nursing care), visualizing the final product, i.e. attending to social needs and, concerning health, individual recovery and population health control(5). Care has been conceptualized as a therapeutic intervention, centered on the patient's need the nurse can attend to. The patient's targets are the most important and nursing care should be aimed at compliance with these targets; defending the thesis that care contains the conciliatory dimension between care practices and individual life ${ }^{(6-8)}$.

Nursing as work comprises three main components: live work, dead work and technology. Live work itself means work in action, creative work that is produced in the act of its accomplishment, can make use of what is given, with some degree of self-management, autonomy to do the work, including the possibility to creatively define and select the techniques and standards of the work process.

Thus, the encounter between the user with health needs and the worker with specific knowledge and practices establishes an encounter of situations that are not necessarily equivalent, resulting in the construction of a space of intersection between user and worker, an encounter and a negotiation in action about the needs. Health practices are the space of worker-user intersection, the place that makes live work in action feasible ${ }^{(9)}$.

Therefore, the establishment of a caregiving nucleus is proposed, which implies producing a process of dialogue and listening, relations of welcoming and bonding. All health professionals are considered care operators, who should not only be qualified concerning clinical aspects, but also regarding soft technologies, i.e. the way to produce welcoming, co-responsibility with the user and bonding ${ }^{(9)}$.

Dead work refers to the products-means that are present in the work as a tool and raw material and which result from previous human work, i.e. they did not exist before its production as a result of a work process performed earlier. Dead work is present as a certain wisdom in knowing how to be and, thus, operating the production of some of these workers' typical products. It is present in the form of a tool workers use to accomplish their specific work every day ${ }^{(9)}$.

On the other hand, technology is the set of knowledge and instruments that express, in the service production processes, the network of social relations in which its agents articulate their practice in a social whole, classifying technologies as hard, soft-hard and soft, supporting the notion that, through an adequate relation between the three types of technology, quality can be produced in the system ${ }^{(9)}$.

Hard technology refers to technological equipment like machinery, as well as organizational standards and structures; soft-hard technology concerns the well-structured knowledge that operates the work process in health and soft technology is the technology of relationships, of bonding, of welcoming, which is produced in live work, in the encounter between health workers and users or patients, at the moment of talking and listening ${ }^{(9)}$.

Health work is centered on live work in permanent action and is executed through soft technologies. When the configuration of this practice takes the form of an encounter between professionals and users, like in the case of the MIN consultation, it corresponds to the accomplishment and production of a caregiving nucleus, i.e. the space of worker-user intersection that permits listening, bonding, welcoming and trust to allow the mother to express her doubts about health care.

The nursing consultation is considered an activity characteristic of the nursing staff, through which systemized care is offered. It is an effective method to identify health problems and the search for solutions. 
Research findings have shown that mothers perceive the nursing consultation as distinguished care, during which the help relation and harmony are promoted in the family group ${ }^{(4)}$. Another study found that the nursing consultation for children is adequate concerning the application of technical-scientific knowledge and basic health actions, appointing that educative aspects need to be improved ${ }^{(10)}$.

These are some elements that constituted the base for this research, which aimed to analyze well child nursing care (WCC) from the perspectives of mothers who attended nursing consultations with their children and distinguish whether this care is procedure or usercentered. This study is part of a broader research that also investigated the view of WCC nursing professionals.

\section{Method}

A qualitative research was accomplished through systematic direct observation of 87 WCC consultations by the MIN and semi-structured interviews ${ }^{(11)}$ with 25 women who attended the consultation with their children. Concerning the interviewed mothers' sociodemographic data, the mean age was 29 years, finished high school education (11 years), housewives (76\%), married (76\%), the children's mean age was 14 months and $84 \%$ of the visits were subsequent.

The techniques were applied until data saturation, i.e. until the data obtained showed some redundancy or repetition ${ }^{(12)}$ and the meaning was understood, according to the researcher's assessment. Before the observation and interviews, participants received information about the research aims and their informed consent was obtained. Their dignity was respected, as well as their right to withdraw from the study at any time.

The following aspects were registered: duration of the WCC consultation, interactions and dialogues established between the MIN and the mother/child users. The interview focused on the aspects of care production, allowing the mothers to freely express how they perceived care, if they were allowed to express their concerns and needs during the consultation and how the MIN treated and interacted with her and her child.

The mothers were approached at the end of the WCC consultation. Twenty interviews were held at the waiting room, aiming to remain distanced from the MIN area and to go deeper in the thematic units, other mothers were identified who authorized interviews at their home, resulting in five interviews, which totaled 25 interviews.

The interviews were recorded and fully transcribed. To analyze the data, thematic analysis was used(11). The notion of theme is linked with an assertion about a certain topic, in the attempt to discover the cores of meaning that are part of communication whose presence or frequency means something for the proposed aim. In qualitative terms, the presence of certain themes indicates the reference values and behavioral models that are present.

Data analysis involved three phases. The first ended with data collection, when the records of WCC consultation observations and interviews were subject to a general review. Exhaustive and repeated reading was necessary, called "floating reading", which helped to establish the initial thematic units, which were confronted with the theoretically established analytic units.

The following thematic units were constructed: a) WCC a priority health program, b) WCC security and information, c) WCC accomplishment of procedures and d) user-centered WCC. In the third phase, the empirical thematic units were considered, correlating them with the theoretical conceptions to establish conclusions on the way to produce nursing care.

This research was developed in line with the ethical guidelines established in Mexican law (Reglamento de la Ley General de Salud en Materia de Investigación para la Salud de México) ${ }^{(13)}$ and received IRB (Coordinación de Investigación en Salud del Estado) approval (CDISNL-011-2004).

\section{Results and Discussion}

\section{Well Child Care: a priority health program}

WCC is fundamental, given the vulnerability of human beings in this phase of the life cycle, which demands periodical and systematic accompaniment, as well as growth and development evaluation(14). In this study, out of 25 interviewed mothers, only one mentioned WCC as a health program that demands follow-up: I bring her for well child follow-up (Int. 20).

In WCC, a health team participates in an alternating or joint way(13), an aspect one of the participants appointed as necessary Maybe it would be a lot to ask for, 
that the clinical nutritionist would be there, the family doctor, the dentist, which is the complete team (Int. 4). The above indicates the need to have the health team to offer comprehensive care, which is one of the fundamental aims of WCC ${ }^{(4,14)}$.

\section{WCC security and information}

The physical screening is one component that permits distinguishing signs of normality or abnormality ${ }^{(3)}$. In this respect, the mothers appointed the following Above all the fact of knowing that things go well, it means checking that his growth is going well, both weight and height, that there is no problem or that it is detected before it can get worse (Int. 4), I bring him for them to check how he is doing and that thing with the foot and that way I already feel safer (Int. 5), They just check, if there's a problem because, as they say, eh, that it's on time, they will be able to check on time, if my child has some problem (Int. 12). The above is in line with another study that indicates that, when the mother perceives that the child's body is examined as a whole, this generates satisfaction with nursing care ${ }^{(15)}$.

One goal of WCC is to prepare the family in order to contribute to improve care quality through health promotion and disease prevention(4). Concerning the above, it was identified that none of the mothers considered the MIN or AMIN as counselors or educators. The information provided is scarce, the following topics are rapidly addressed: food, early stimulation activities and accident prevention. In this respect, there is evidence that the parents would like to discuss themes like: sleep and rest patterns, child development, family and social context with health professionals. Besides, it is recommended that emerging illnesses like domestic violence and drugs use and consumption be explored(2).

This situation was evidenced in the interviews The main thing for me is that the child can develop, I've just told her that my child was very inhibited, that he was afraid of my brothers, because their voice is very strong and he just heard them talk and was very scared, I asked if nothing was happening, but she didn't tell me anything about the child's behavior (Int. 15), They should give us more orientations about the children, because sometimes you don't know, you ask them - Look, can the child do that? And they don't tell us (Int. 13).

In addition, the mothers indicated the need for the nursing staff to have specialized and updated knowledge, as well as training and updates: The nurse is specializing in children, but I would like to have a bit more, I think that one never stops learning, there are always advances (Int. 10).
In addition, it was reported that the nursing staff itself perceives a lack of training, of previous experience, that they had not worked with children or has more hospital than community health experience ${ }^{(14)}$.

\section{WCC accomplishment of procedures}

The nursing consultation permits identifying health-disease problems through the accomplishment and assessment of care with a view to users' health promotion, protection, recovery and rehabilitation. It is a form of comprehensive care. WCC implies the accomplishment of procedures like: anthropometric measures, measuring vital signs and applying vaccines, among others ${ }^{(4)}$. This should be done in combination with other activities, not separately. The mothers signaled that They check weight and height (Int. 7), Because that's it, well child care, to check measures, how tall he is, how much he weight (Int. 8), The child had an appointment for development, height, weight and vaccination control (Int. 9).

On the other hand, the duration of the consultation has been associated with care quality ${ }^{(16)}$. At the service under analysis, the programmed duration of a WCC consultation is 10 minutes. In this respect, the mothers identified the consultations as fast and commented that, sometimes, waiting a long time to be attended is not worth it in comparison with the fast and routine care delivery: The consultation is fast here, I didn't spend more than 5 minutes (Int. Mother 8). Sometimes I spend a little time, now I spent almost 15 minutes, it was very fast, each time they do the same, they weight him, check his stomach and measure his head, that's all, why come and wait here one hour and a half (Int. Mother 19). Today, health services work in an environment with limited resources, which is why the available resources have to be adapted to the users' needs $^{(17)}$.

The care model restricted to the consultation room, based on rapid consultations, does not attend to the demands for comprehensive health promotion. Group WCC models have been proposed which, according to the research reports, are efficient and do not affect the parents' satisfaction with care, as they offer the advantage of experience exchange among the parents about child care ${ }^{(17)}$.

When analyzing what occurs at the intersection between workers and users, it was observed that the relation involves dialogues, actually monologues by the MIN and directed at the mother, without offering the opportunity to express her doubts. The MIN does not 
get involved with the mother, the child who is the key object of care seems to be absent in the relation with the MIN. The programmed time for the consultation and the care protocol to be followed trap the MIN's live work, who is centered on the accomplishment of procedures during the 10 minutes available for the visit, the hard technologies almost fully capture the live work ${ }^{(5-6,9)}$.

Concerning the establishment of a caregiving nucleus through the soft technologies, which permit trust and welcoming, after the consultation, the mothers mentioned after the consultation that they did not know the name of the MIN who had attended them. The MIN does not identify herself and delivers care without greeting the mother: The consultation was short, it took about 5 minutes, I don't know who attended, she didn't tell me her name (Int. 4), She didn't even greet me, she allowed only me to pass and asked ihow old is the child?, the way they behave does not seem right at all, they don't look at you, they don't greet you, maybe the workload is high, they are constantly passing people, but at least a greeting (Int. 24).

Also, it was observed that the MIN only asks short questions about the physical aspects of growth, live work is commanded by dead work, which cannot be considered as an actual nursing consultation(15). It is centered on the accomplishment of procedures My next appointment is in 4 months, but who knows if I'll come, the only thing they ask is if he's eating well, what food we give him, they ask, but don't tell you anything else (Int. 8). The consultation is mechanic, they don't talk much to you, there's no relation with the patient, they see him as object $X$, like an animal, I don't know, they could ask you your name: Juanita or Maria? To tell you: Look, how's Juanita doing? Be part of the patient's environment at that moment, of his sphere, a much more mutual relation that isn't mechanic? (Int. Mother 25).

Another aspect observed is that, on most occasions, it is the mother who attends WCC with the child, in line with another study ${ }^{(4)}$. At other times, however, a family member accompanies the child, mainly the grandmother or the father. It was observed, however, that when both attend (father and mother with their child), the father is not allowed to enter, the participants commented It would be good if they entered to know about the children, that's what I tell my husband as, when we go out, he takes care of the child but, ever since I've seen what the nurse says, mother, baby and folder, I tell my husband - They won't let you get in, better stay there - and then he waits there (Int. 22), Nobody else can come in with the child, no men can come in and I would like the man to come in so they would involve him, so that he also takes responsibility, communication is reaffirmed more between the couple, I tell them - I want my husband to come in - and they told me - That's not allowed here, only you - and they say - So why do I go, it's better for my mother or your sister to go along - They even feel bad (Int. 25).

\section{User-centered WCC}

One quality of the nursing consultation is the fact that it includes health promotion and protection, contributes for individuals and their families to take responsibility and act for the benefit of their own health(4). Integrality implies that primary care should adequately recognize the user's health-related needs and offer resources to treat them(18).

One participant mentioned flexibility when she had to reschedule an appointment: Once my daughter was going to participate in the mother's day festival, look, it was my first festival, and I - Please, I would like to change the appointment - and they told me - is it something very urgent, madam? Unless it's something very urgent we change your appointment, because it's already programmed - so I told them the truth - It's my first mother's day festival, my daughter is going to present, how can I not attend - and they said - don't worry, we'll rearrange you - and I liked it that I went to the festival to see my daughter (Int. Mother 14).

The above evidences that the MIN can listen to what the mothers express and answer their needs, was flexible concerning institutional standards by changing the appointment. Hence, the MIN demonstrates selfgovernment, autonomy that allows her to be flexible, as welcoming demands flexible service standards and routines, the care focus is on the user and solving her problems, so as to construct a patient-care care nucleus $^{(9)}$.

Moreover, it was identified that room exists for user-centered WCC. The MIN is capable of producing live work, creative work, based on her self-government that allowed here to go beyond the institutional configuration and attend to users' needs, which was facilitated by the bond established when the MIN attends the mother during her pregnancy and, subsequently, delivers child care she was lovable, she was really lovable, she answered the questions I asked her (Int. Mother 11), What I liked most is that she remembered me, that she had attended during my pregnancy and she said: How are you? reviewed the file and said - Ah, I see that you didn't breastfeed, what happened? But what I liked most is that she remembered (Int. Mother 14), Ever since I was expecting the child I had contact with her and now 
too, it's as if I feel more confident to ask her something, because it's the same person (Int. Mother 22).

Nevertheless, the MIN needs to act based on her self-government, i.e. that care protocols should not command her work, that she should aim to develop and improve her communication skills to serve as a care operator, considering that, without communication, there is no humanization, and the principle of care comprehensiveness cannot be achieved(8-18).

\section{Final considerations}

The WCC the MIN provides is centered on the accomplishment of procedures like weight and height measurement. Child nutrition and immunization topics are rapidly addressed. The mothers characterized the activity as fast and mechanic, which cannot be considered comprehensive well child care. Therefore, the WCC is directed by hard technologies, i.e. by care protocols and institutional configurations, which gives rise to procedure-centered care. The duration of the consultation emerged as a factor that directs at procedures.

It is through soft technologies that a caregiving nucleus can be constructed that permits user-centered care, as the mothers perceived that trust is developed and established through interaction with the MIN, provided that these professionals deliver care during pregnancy and subsequent child care.

\section{References}

1. Kuo AA, Inkelas M, Lotstein DS, Samson KM, Schor EL, Halfon N. Rethinking well-child care in the United States: an international comparison. Pediatrics. 2006 Oct;118(4):1692-702.

2. Norma Oficial Mexicana NOM-031-SSA2-1999, de 22 de septiembre de 1999 (Méx). Para la atención a la salud del niño. [acesso 24 mar 2011]. Disponível em: http:// www.salud.gob.mx/unidades/cdi/nom/031ssa29.html

3. Instituto Mexicano del Seguro Social. Normatividad en Salud Infantil: manual de procedimientos para la vigilancia de la nutrición, crecimiento y desarrollo del menor de 5 años. México; 1998. 84 p.

4. Ribeiro CA, Silva CV, Saparolli ECL. Consulta de enfermagem à criança num projeto de integração docente assistencial: experiência de implantação. Acta Paul Enferm. 2002;15(2):79-88.
5. Merhy EE. Saúde: A cartografia do trabalho vivo. São Paulo (SP): Hucitec; 2002. 189 p.

6. Almeida MCP, Rocha SMM. Considerações sobre enfermagem enquanto trabalho. In: Almeida MCP, Rocha SMM, organizadoras. O Trabalho de enfermagem. São Paulo (SP):

Cortez; 1997. p. 15-26.

7. Waldow VR. O Cuidado na Saúde: as relações entre o eu, o outro e o cosmos. Petrópolis (RJ): Vozes; 2004. $237 \mathrm{p}$.

8. Ayres JRCM. Tão longe, tão perto: o cuidado como desafio para o pensar e o fazer nas praticas de saúde. In: Saeki T, Sousa MCB, organizadoras. Cuidar: tão longe... tão perto. Ribeirão Preto (SP): Escola de Enfermagem de Ribeirão Preto da Universidade de São Paulo; 2002. p. 13-26.

9. Merhy EE. Em busca do tempo perdido: a micropolítica do trabalho vivo em saúde. In: Merhy EE, Onocko R, organizadores. Agir em saúde: um desafio para o público. 2nd ed. São Paulo (SP): Hucitec-Abrasco; 1997. p. 71-112.

10. Saparolli ECL, Adami NP. Avaliação da qualidade da consulta de enfermagem à criança no Programa de Saúde da Família. Acta Paul Enferm. 2007;20(1):55-61. 11. Minayo MC. O desafio do conhecimento. 12 ed. São Paulo (SP): Hucitec-Abrasco; 2010.

12. Fontanella BJB, Ricas J, Turato ER. Amostragem por saturação em pesquisas qualitativas em saúde: contribuições teóricas. Cad Saúde Pública. 2008;24(1):17-27.

13. Secretaría de Salud. Reglamento de la Ley General de Salud en Materia de Investigación para la Salud. [acesso 13 jan 2010]; Disponivel em: http://www. salud.gob. $\mathrm{mx}$

14. Campos RM, Ribeiro CA, Silva CV, Saparolli EC. Consulta de enfermagem em puericultura: a vivência do enfermeiro na Estratégia de Saúde da Família. Rev Esc Enferm USP. jun 2011;45(3):566-74.

15. Nunes CB, Silva CV, Fonseca AS. Ouvindo as mães sobre a consulta de enfermagem a seus filhos. Acta Paul Enferm. 2003;16(3):31-9.

16. Halfon N, Inkelas M, Mistry R, Olson L. Satisfaction with health care for young children. Pediatrics. 2004 June;113(2):1965-72. 
17. Blank D. A puericultura hoje: um enfoque apoiado em evidências. J Pediatria. [periódico na Internet]; 2003; [acesso 13 jan 2010]; 79,supl 1:S13-22. Disponível em: http:// www.scielo.br/scielo.php?script=sci_arttext\&pid=S002175572003000700003\&lng=en\&nrm=iso

18. Starfield B. Atenção Primária: equilíbrio entre as necessidades de saúde, serviços e tecnologia. Brasília (DF): Ministério da Saúde; 2002. 